\title{
Clinical Chemoprevention
}

National Cancer Institute

\section{Source}

National Cancer Institute. Clinical Chemoprevention. NCI Thesaurus. Code C15782.

Chemoprevention use in a clinical setting. 